\title{
Investigations on the Effects of Cement Replacement and Calcium Chloride Addition on Selected Properties of Coconut Husk Fibre-Reinforced Roofing Tiles
}

\author{
Abel.O. Olorunnisola ${ }^{1, a^{*}}$ and Anthony .O. Adeniji ${ }^{1, b}$ \\ ${ }^{1}$ Department of Wood Products Engineering, University of Ibadan, Nigeria \\ aabelolorunnisola@yahoo.com, btoneeden@live.co.uk
}

Keywords: coconut husk, rice husk ash, calcium carbide waste, cement-bonded composite

\begin{abstract}
Provision of adequate and affordable housing is one of the continuing challenges posed by unprecedented urbanization in Nigeria and many other African countries. One of the solutions to this chronic problem is the development of non-conventional low cost building materials from recyclable agro-industrial wastes. This study was conducted to investigate the effects of $\mathrm{CaCl}_{2}$ addition and partial replacement of cement with Rice Husk Ash (RHA) and calcium carbide waste (lime) on the density, water resistance and impact strength of cementbonded composite roofing tiles reinforced with coconut husk (Cocos nucifera) fibres. Results indicated that $\mathrm{CaCl}_{2}$ enhanced impact strength and dimensional stability of the composite samples, while RHA and lime lowered the impact strength of the roofing tiles.
\end{abstract}

\section{Introduction}

The need to improve housing supply in developing countries is great. So also are the needs to manage agro-industrial wastes in a sustainable manner and reduce the use of cement in building construction. Accumulation of unmanaged wastes results in environmental pollution. Recycling of such wastes, particularly agro-industrial wastes, as sustainable building construction materials appears to be viable solution not only to pollution problems but also to the problem of economic design of buildings.

The major types of roofing materials available in Nigeria are corrugated iron and aluminum sheets, slates and asbestos sheets. While corrugated iron sheets are prone to rusting and can be noisy when it is raining, asbestos roofing sheets are relatively expensive and have been outlawed in many countries due to the carcinogenic nature of asbestos fibres. Cement-bonded composites (CBCs) represent an important class of engineered construction materials in which some agroindustrial wastes could be used as partial replacement of cement, while others could serve as fibre reinforcement. Fibrous materials suitable for cement-bonded composite roofing and ceiling tile production in Nigeria include bamboo (Bambusa vulgaris), rattan cane, sugar cane bagasse (Saccharum officinarum), raffia palm (Raphia africana), luffa (luffa cylindrica), Cissus populnea, and coconut husk (Cocos nucifera Linn) among others [1-6].

There are about three million coconut palm trees producing approximately 70 million coconuts annually in Nigeria [7]. The average mature coconut weighs $680 \mathrm{~g}$ about $42 \%$ of which is made up of the husk [8]. The husk fibres, largely treated as waste, are a candidate material for CBC reinforcement. Potential agro-industrial waste products for partial replacement of cement in the country include welder's used carbide waste (lime) derived from ethyne $\left(\mathrm{C}_{2} \mathrm{H}_{2}\right)$ gas, by the action of cold water on calcium carbide and plant ashes that have relatively high silica content and are therefore suitable as a pozzolana, including, RHA. It is generally believed that calcium 
carbide residue is rich in calcium hydroxide and behaves like hydrated lime. Hence, is has also been recommended as potential material for partial replacement of cement in concrete works [9].

The aim of this study was to evaluate the effects of $\mathrm{CaCl}_{2}$ addition and partial replacement of cement on selected properties of coconut husk fibre-reinforced composite roofing tiles.

\section{Methodology}

Coconut fibres removed from the husk, were separated into individual strands and cut into 25 $\mathrm{mm}$. Rice husk was air-dried for five days, charred and incinerated at $700^{\circ} \mathrm{C}$ into white ash. Welder's used carbide waste (lime) obtained from a mechanical workshop was air-dried, pulverized and sieved. The fibre (2\%) was mixed with Portland cement, river sand, water and colouring material (Iron II Oxide), using a pre-determined water -cement ratio (control). For set I of the experimental samples, $\mathrm{CaCl}_{2}$ was added at 2, 3 and $4 \%$ levels. Iron II Oxide was added at the rate of $2 \%$. For sets II and III, cement was partially replaced with RHA and lime respectively at 5, 10 and $15 \%$. All percentages were based on the mass of cement. Triplicate samples of 600 (L) $x 300$ (B) x 6 (T) mm corrugated roofing tiles were produced with each mixture, vibrated for 60 seconds at $50 \mathrm{~Hz}$ and cured for 28 days. The samples were tested for moisture content, density, impact energy, water absorption and thickness swelling using standard methods earlier reported $[10,11]$. Analysis of variance was conducted at $5 \%$ level of significance.

\section{Results and Discussion}

\section{Density and Moisture Content of the Tiles}

Samples of the red-coloured coconut husk fibre-reinforced composite roofing tiles produced are shown in Fig.1. The average density ranged between 1.3 and $1.6 \mathrm{~g} / \mathrm{cm}^{3}$ at an acceptable moisture content range of $2.5-5.5 \%$ (dry basis) Table 1 . However, analysis of variance (Table 2) showed that neither the addition of $\mathrm{CaCl}_{2}$ nor partial replacement of cement with RHA and lime had significant effect on density, though the densities of samples in which cement was partially replaced were generally lower in conformity with the findings from similar previous studies $[10,11]$. This is an indication that cement could be partially replaced to reduce the weight of the composite roofing tiles.

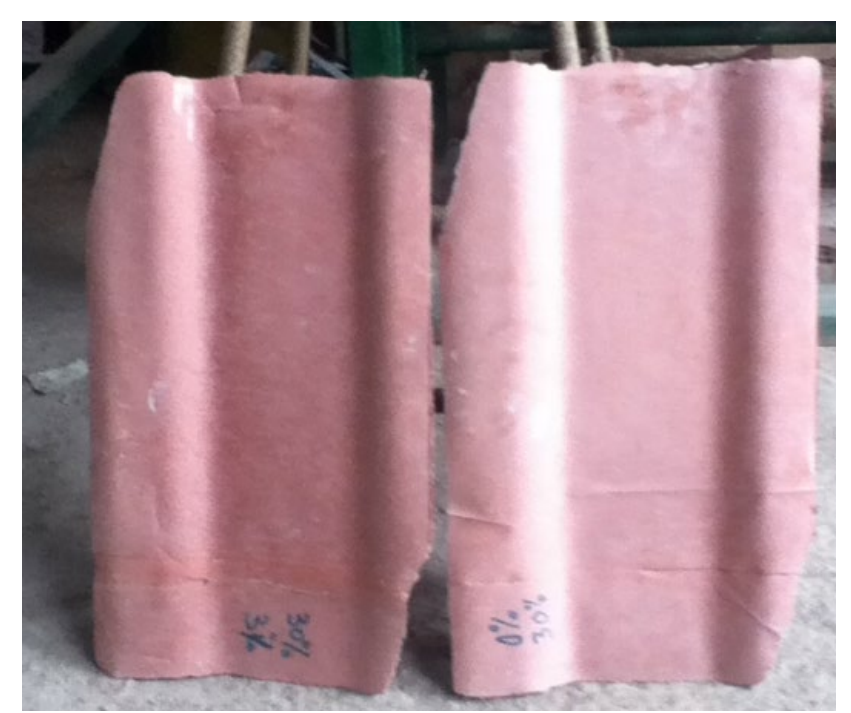

Fig. 1. Samples of coconut husk fibre-reinforced roofing tiles. 
Table 1: Moisture Content and Density of the Composites.

\begin{tabular}{|c|c|c|c|}
\hline $\begin{array}{c}\text { Sample } \\
\text { Composition }\end{array}$ & $\begin{array}{c}\text { Average Moisture } \\
\text { Content (\%) }\end{array}$ & $\begin{array}{c}\text { Average Density } \\
\left(\mathrm{g} / \mathrm{cm}^{3}\right)\end{array}$ & $\begin{array}{c}\text { Normalized } \\
\text { Density }^{1}\end{array}$ \\
\hline $5 \%$ RHA & 3.8 & 1.5 & 0.94 \\
\hline $10 \%$ RHA & 3.4 & 1.3 & 0.81 \\
\hline 15\% RHA & 3.7 & 1.4 & 0.87 \\
\hline 5\% Lime & 4.1 & 1.5 & 0.94 \\
\hline 10\% Lime & 4.3 & 1.6 & 1.0 \\
\hline 15\% Lime & 4.0 & 1.4 & 0.87 \\
\hline $2 \% \mathrm{CaCl}_{2}$ & 4.9 & 1.6 & 1.0 \\
\hline $3 \% \mathrm{CaCl}_{2}$ & 2.5 & 1.7 & 1.1 \\
\hline $4 \% \mathrm{CaCl}_{2}$ & 3.0 & 1.4 & 0.87 \\
\hline Control & 5.5 & 1.6 & 1.0 \\
\hline
\end{tabular}

${ }^{1}$ The average specimen density divided by the average density of control specimen

Table 2: Analysis of Variance of the Effect of Partial Replacement of Cement on Density.

\begin{tabular}{lcccccc}
\hline \multicolumn{1}{c}{$\begin{array}{l}\text { Source of } \\
\text { Variation }\end{array}$} & SS & $d f$ & MS & F & P-value & F crit \\
\hline Between & & & & & & \\
Groups & 0.230427 & 6 & 0.038405 & 2.451591 & 0.078271 & 2.847726 \\
Within Groups & 0.219312 & 14 & 0.015665 & & & \\
& & & & & & \\
Total & 0.449739 & 20 & & & & \\
\hline
\end{tabular}

\section{Impact Resistance of the Roofing Tiles}

The average impact resistance of the roofing tiles ranged between 0.31 and $0.53 \mathrm{~J}$. These values are slightly higher than the range of values $(0.19-0.22 \mathrm{~J}$ reported for banana fibre reinforced roofing tiles produced from similar cementitious admixtures [11]. Also, as in a similar study on rattan-cement composite roofing tiles [2], RHA had more negative effect on the impact resistance than waste carbide lime. However, neither the addition of $\mathrm{CaCl}_{2}$ nor partial replacement of cement had significant effect on the impact resistance of the tiles, suggesting that the two substitution materials could be used without compromising the impact resistance of the composite tiles. A fairly strong positive correlation $\left(\mathrm{R}^{2}=0.51\right)$ was observed between impact strength and density of composite roofing tiles indicating density may be a good factor for determining their impact resistance.

Table 3: Impact Energy Resistance of the Composites.

\begin{tabular}{|c|c|}
\hline $\begin{array}{c}\text { Sample } \\
\text { Composition }\end{array}$ & $\begin{array}{c}\text { Average Impact Energy } \\
(\mathbf{J})\end{array}$ \\
\hline 5\% RHA & 0.36 \\
\hline 10\% RHA & 0.32 \\
\hline 15\% RHA & 0.40 \\
\hline 5\% Lime & 0.36 \\
\hline
\end{tabular}




\begin{tabular}{|c|c|}
\hline $10 \%$ Lime & 0.40 \\
\hline $15 \% \mathrm{Lime}$ & 0.36 \\
\hline $2 \% \mathrm{CaCl}_{2}$ & 0.45 \\
\hline $3 \% \mathrm{CaCl}_{2}$ & 0.45 \\
\hline $4 \% \mathrm{CaCl}_{2}$ & 0.49 \\
\hline Control & 0.45 \\
\hline
\end{tabular}

\section{Water Absorption and Thickness Swelling}

The average water absorption and corresponding thickness swelling values obtained are presented in Figure 2. The water absorption values ranged from 1.0 to 3.9\%, while the thickness swelling values ranged from 0.9 to $2.0 \%$ after 24 hour-immersion in cold water. These values compare favourably with established data on sorption properties of cement-bonded systems reinforced with organic fibres including fibre-reinforced composite roofing tiles produced with partial replacement of cement with lime and $\mathrm{CaCl}_{2}$ [11-14]. While $\mathrm{CaCl}_{2}$ at the three levels of application had no significant effect on the WA, the effect on TS was positive and significant. However, while partial replacement of cement with both RHA and lime led to significant increase in WA, the effect on TS was not significant.

Water absorption is a good indicator of the durability of the bioplastics material as the presence of water can cause cracking (associated with shrinkage and swelling phenomena), and premature biodegradation [15]. The relatively low water absorption values recorded is, therefore, desirable. The correspondingly low thickness swelling is also a good indicator of dimensional stability. As shown in Figures 3, 4 and 5, there were positive correlations between density and water absorption, density and thickness swelling, as well as water absorption and thickness swelling. Similar results were reported for cement-bonded rattan and coconut husk composites [15].

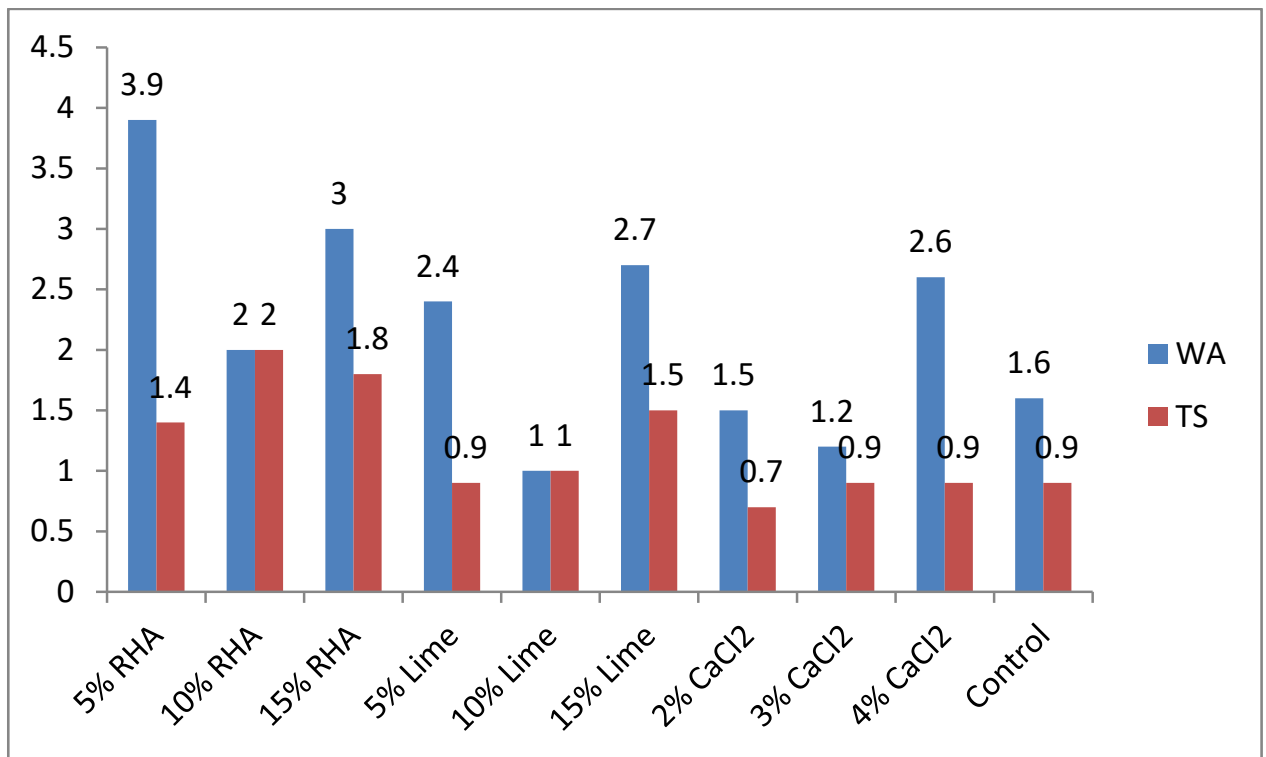

Fig.2. Water absorption by, and thickness swelling of the composite roofing tiles. 


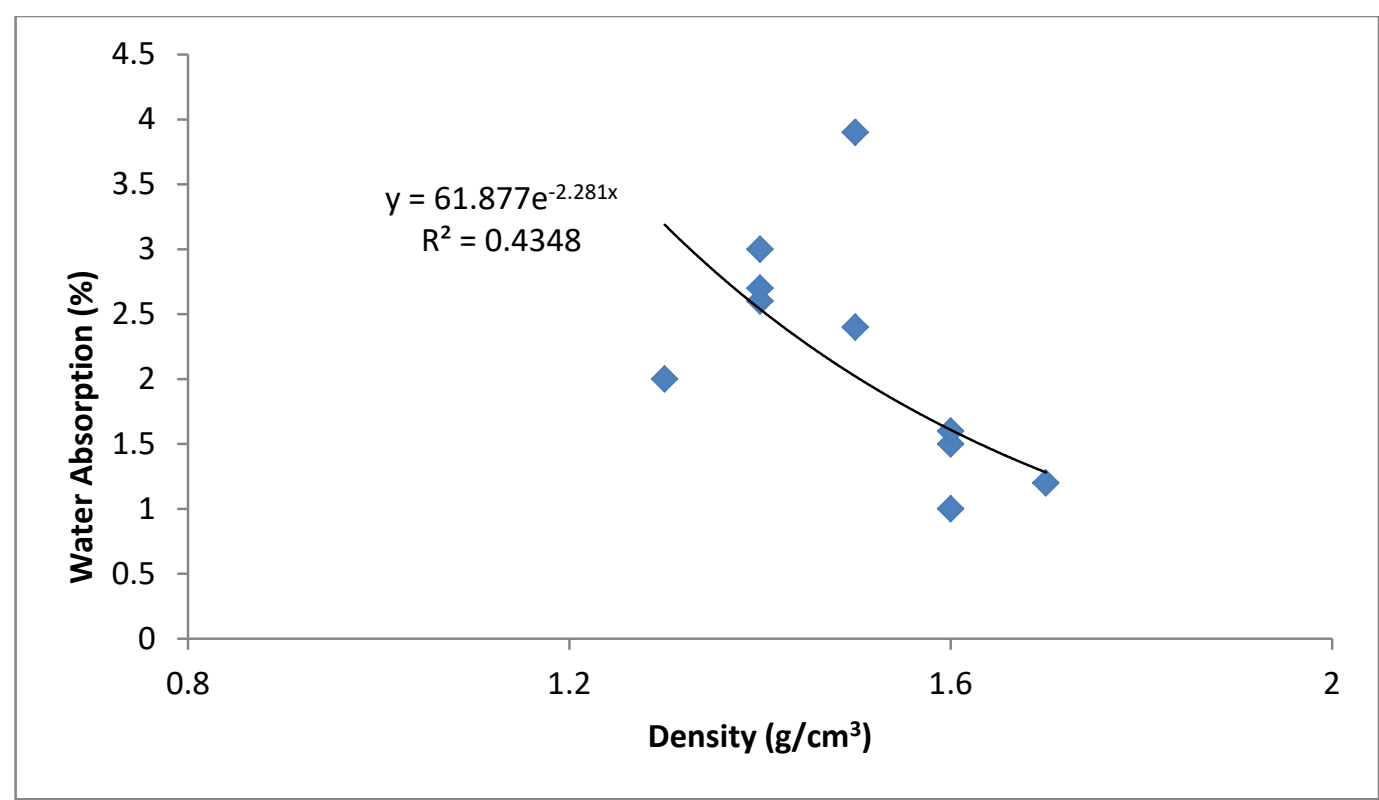

Fig. 3. Correlation between density and water absorption.

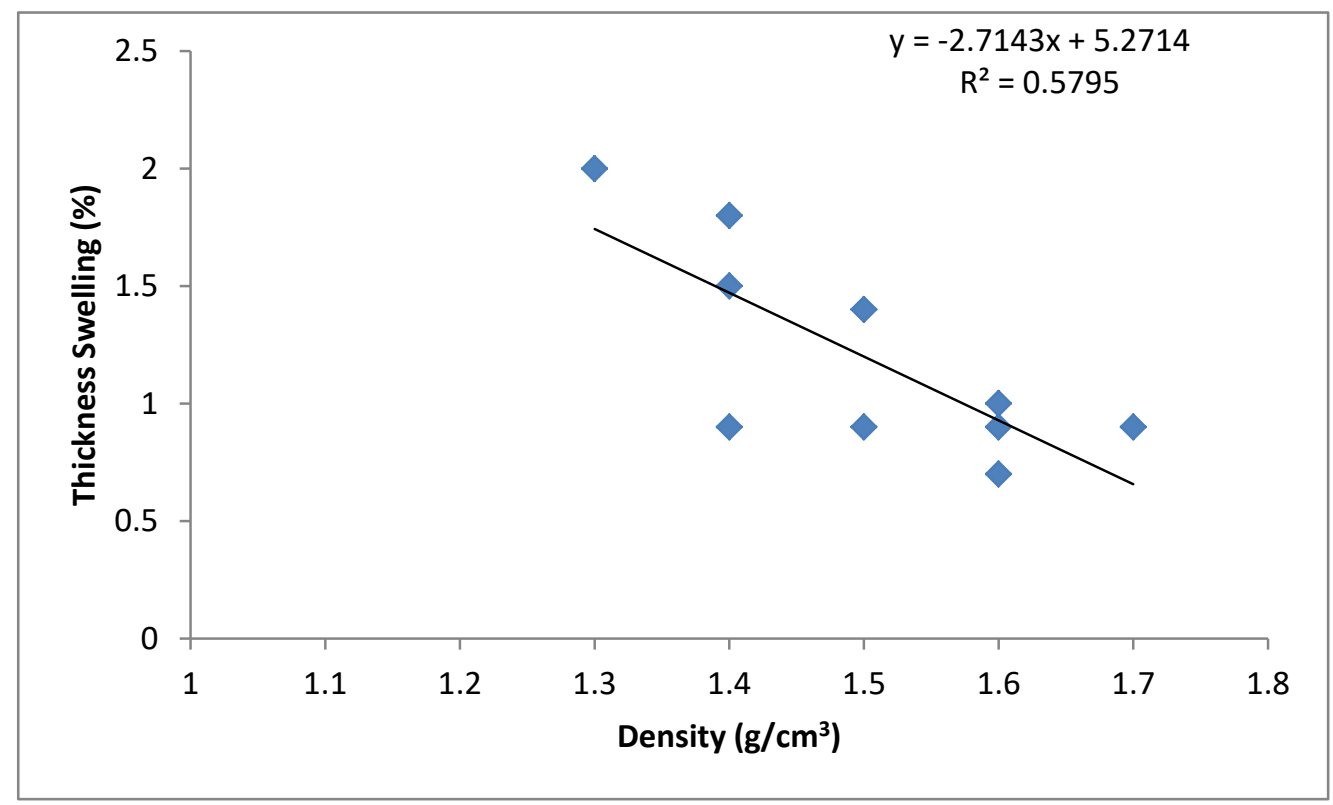

Fig.4. Correlation between density and thickness swelling. 


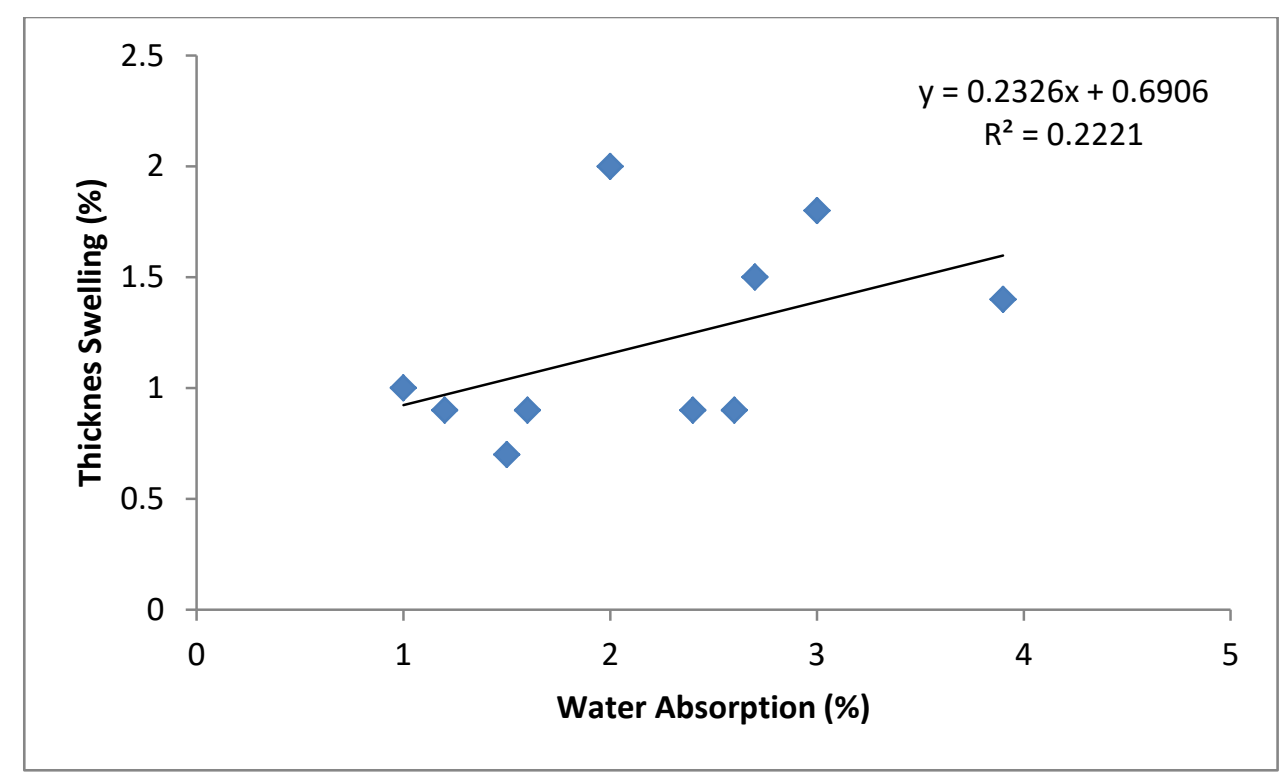

Fig.5. Correlation between Water absorption and thickness swelling.

\section{Conclusion}

This study showed that the use of $\mathrm{CaCl}_{2}$ in the production of coconut husk fibre-reinforced roofing tiles would be beneficial in improving dimensional stability. Also, partial replacement of cement with RHA and lime up to 15\% could help in reducing the weight (and perhaps cost of production) without having any deleterious effects on the water and impact energy absorption by the roofing tiles.

\section{References}

[1] A.O. Olorunnisola, Harnessing the forester's harvest for sustainable development, The Publishing House, University of Ibadan, Nigeria, 2013.

[2] A.O. Olorunnisola, A. Ogundipe, Impact and water resistance of rattan composites produced with rice husk ash and welder's carbide waste as partial replacement for portland cement, in F. Caldeira (ed.), Towards Forest Products and Processes with Lower Environmental Impact, University of Fernando Pessoa, Porto, Portugal (2014) 199-218.

[3] T.E. Omoniyi, Development and evaluation of roofing sheets from bagasse-cement composite, PhD Thesis, Department of Agricultural \& Environmental Engineering, University of Ibadan, Nigeria, 2009.

[4] R.S. Odera, O.D. Onukwuli, E.C. Osoka, Tensile and compressive strength characteristics of raffia palm fibre-cement composites, Journal of Emerging Trends in Engineering and Applied Sciences 2-2 (2011) 231-234.

[5] M.O..Lazeez, Production and evaluation of cement-bonded composite using okra fibre as a potential reinforcement material, Project report, Department of Agricultural \& Environmental Engineering, University of Ibadan, Nigeria, 2014 
[6] K. Amoo, O.O. Adefisan, A.O. Olorunnisola, Development and evaluation of cement-bonded composite tiles reinforced with Cissus populnea fibres, International Journal of Composite Materials 64 (2016) 133-139.

[7] A.A. Badmus, Coconut processing technologies in Nigeria-A critical appraisal, A seminar paper, Department of Agricultural \& Environmental Engineering, University of Ibadan, Nigeria, 2009.

[8] G.A. Badmus, N.A. Adeyemi, O.K. Owolarafe, Development of an improved manual dehusking lever, Nigerian Journal of Palms and Seeds, 16(2007) 36-47.

[9] WA Al-Khaja, Potential use of carbide lime waste as an alternative material to conventional hydrated lime of cement-lime mortars, Engineering Journal of Qatar University, 5(1992) 57-67.

[10] S.A. Nta, A.O. Olorunnisola, Experimental production and evaluation of cement bonded composite pipes for water conveyance, International Journal of Composite Materials 6-1 (2016) 9-14.

[11] A.O. Olorunnisola, F. Ope-Ogunseitan, Effects of lime and $\mathrm{CaCl} 2$ on impact strength and dimensional stability of banana fibre- reinforced composite roofing tiles, Proc. of the 15th Inorganic-Bonded Fiber Composites Conference, Fuzhou Empark Exhibition Grand Hotel, Fuzhou, China, (2016) 76- 84.

[12] A.O. Oyagade, Thickness swelling components and water absorption of cement-bonded particleboards made from gmelina wood, bagasse and coconut husk, Nigerian Journal of Forestry 30-1 (2000) 10-14.

[13] B. Ajayi, Preliminary investigation of cement-bonded particleboard from maize stalk residues, The Nigerian Journal of Forestry, 32-1 (2002) 33-37.

[14] A.O. Olorunnisola, O.O. Adefisan, Trial Production and Testing of Cement-bonded Particleboard from Rattan Furniture Waste, Wood \& Fiber Science 3-1 (2002) 116-124.

[15] A.O. Olorunnisola, Compressive strength and water resistance behaviour of cement composites from rattan and coconut husk, Journal of Tropical Forest Resources 20-2 (2004) 113. 